\title{
Climate change and lung health: presidential failure, professional responsibility
}

\author{
Nicholas S Hopkinson, ${ }^{\oplus 1}$ Nicholas Hart, ${ }^{2}$ Gisli Jenkins, ${ }^{\oplus 3}$ \\ Margaret Rosenfeld ${ }^{4}$ Alan Robert Smyth, ${ }^{\oplus 5}$ Alexander J K Wilkinson, ${ }^{\oplus 6}$ \\ Naftali Kaminski ${ }^{7}$
}

\author{
Ignorance, allied with power, is the most \\ ferocious enemy justice can have. James \\ Baldwin
}

On the eve of President Trump's inauguration in 2017, we published an editorial setting out the threat that climate change poses to lung health. We urged the incoming President to face up to his responsibilities and take steps to address this growing existential threat. ${ }^{1}$ We drew a parallel with the actions of two conservative leaders in the 1980s, Ronald Reagan and Margaret Thatcher who, faced with unequivocal scientific evidence, led the decisive steps necessary to avert the destruction of the ozone layer. ${ }^{2}{ }^{3}$ Rather than being contrary to his stated goals, acting on climate change, we wrote 'is one way in which President Trump can make good on his promises to improve the wellbeing of Americans, increase America's energy independence, and act with fiscal prudence. Investing in green infrastructure creates jobs. It reduces healthcare costs, as $1 / 4-1 / 3$ of the costs of decarbonising come straight back as health economic gains'. ${ }^{4}$

Sadly, 2 years on our worst fears have been realised. The USA is experiencing an unprecedented wave of natural disasters attributable to climate change, including widespread wildfires, destructive storms

\footnotetext{
${ }^{1}$ National Heart and Lung Institute, Royal Brompton and Harefield NHS Foundation Trust and Imperial College, London, UK

'Lane Fox Respiratory Service, Guy's \& St Thomas' NHS Foundation Trust, London, UK

${ }^{3}$ Centre for Respiratory Research, University of

Nottingham, Nottingham, UK

${ }^{4}$ Pulmonary Medicine, Seattle Children's Hospital,

Seattle, Washington, USA

${ }^{5}$ Division of Child Health, Obstetrics \& Gynaecology,

University of Nottingham, Nottingham, UK

${ }^{6}$ Respiratory Department, East and North Hertfordshire NHS Trust, Stevenage, UK

${ }^{7}$ Yale School of Medicine Shield Education Patient Care Research Internal Medicine, Yale School of Medicine Shield Education Patient Care Research, New Haven, Connecticut, USA

Correspondence to Dr Nicholas S Hopkinson, National Heart and Lung Institute, Royal Brompton and Harefield NHS Foundation Trust and Imperial College, London SW3 6NP, UK; n.hopkinson@ic.ac.uk
}

and temperature swings. However, rather than providing global leadership, the Trump administration has not merely abdicated responsibility but is actively sabotaging efforts to mitigate climate change by announcing plans to withdraw from the Paris Climate accords. ${ }^{5}$ Clear evidence in the most recent Intergovernmental Panel on Climate Change report sets out the implications of a failure to limit ceiling temperature increase to $1.5^{\circ} \mathrm{C} .{ }^{6}$ With a rise of $2^{\circ} \mathrm{C}$, an ice-free Arctic could be expected to happen once every 10 years. Keeping to $1.5^{\circ} \mathrm{C}$ of warming, lowers this to once every 100 years.

Compiled by 13 US federal agencies, the fourth National Climate Assessment (NCA) spells out the consequences of climate change for communities, the economy, ecosystems, water, health, agriculture, infrastructure, tourism and recreation in the USA. ${ }^{7}$ The report states 'Climate-related risks will continue to grow without additional action. Decisions made today determine risk exposure for current and future generations and will either broaden or limit options to reduce

\begin{tabular}{|c|c|}
\hline Action & Benefit \\
\hline Establish leadership on climate change & $\begin{array}{l}\text { Reverse decision to leave the Paris Climate Agreement. } \\
\text { Appoint officials with appropriate expertise and } \\
\text { understanding of the science behind climate change. }\end{array}$ \\
\hline $\begin{array}{l}\text { Acknowledge scale of the problem and stop conflating } \\
\text { weather with climate }\end{array}$ & $\begin{array}{l}\text { Give business a clear message that low carbon is a stable } \\
\text { opportunity for investment. } \\
\text { Supports international efforts to reach agreement. }\end{array}$ \\
\hline $\begin{array}{l}\text { Use the instruments of government to drive investment } \\
\text { and create markets }\end{array}$ & $\begin{array}{l}\text { Create jobs. } \\
\text { Drive innovation. }\end{array}$ \\
\hline Implement Science based policies & $\begin{array}{l}\text { Repopulate government advisory boards with } \\
\text { environmental experts and fund independent research. }\end{array}$ \\
\hline Move to clean energy & $\begin{array}{l}\text { Reduce } \mathrm{CO}_{2} \text { emissions. } \\
\text { Continue shift to renewable technologies. } \\
\text { Fund research into new technologies. } \\
\text { Reverse decisions to increase drilling. }\end{array}$ \\
\hline $\begin{array}{l}\text { Accelerate the move away from use of hydrofluorcarbons } \\
\text { (HFCs) }\end{array}$ & $\begin{array}{l}\text { These are powerful greenhouse gases. } \\
\text { Alternative solutions require innovation. }\end{array}$ \\
\hline Prioritise active transport and public transport & $\begin{array}{l}\text { Reduce } \mathrm{CO}_{2} \text { emissions. } \\
\text { Improve air quality. } \\
\text { Improve health and fitness. }\end{array}$ \\
\hline
\end{tabular}

the negative consequences of climate change. While Americans are responding in ways that can bolster resilience and improve livelihoods, neither global efforts to mitigate the causes of climate change nor regional efforts to adapt to the impacts currently approach the scales needed to avoid substantial damages to the U.S. economy, environment, and human health and well-being over the coming decades.'

Despite being produced by his own government agencies, The President dismissed the National Climate Assessment (NCA) report, ${ }^{8}$ and has instead appointed climate change deniers and officials with previous connections to the fossil fuel industry to the Environmental Protection Agency (EPA). ${ }^{9} 10$ Not only have investments in green energy not been continued, there have been active attempts to undermine the progress that has been achieved by the previous administration. Trump's executive order, issued on 3 February 2017, which requires a reduction of regulations, has been used by the new EPA leadership as a mandate to weaken environmental policies. The most important of these is the repeal of the Clean Power Plan Rule which allowed the EPA to assign each state a goal for limiting emissions from existing power plants and to switch from coal to natural gas or to build wind or solar farms. Other 'deregulations' include plans to weaken greenhouse gas and fuel economy targets for automobiles and trucks, and the relaxation of rules restricting mercury release by coal-burning power plants. ${ }^{11}$ Finally, following its plan to increase the availability of fossil fuels, the Trump administration has announced 
a policy that will allow increased offshore drilling, near and at national parks, a policy that beyond its effects on increasing greenhouse gas emissions, could lead to environmental disasters as happened with recent oil spills from drilling sites. ${ }^{12}$ It has been estimated that the immediate health effects of the Trump administration's antienvironmental policies will cost the lives of 80000 US residents per decade and lead to respiratory problems for more than one million people. ${ }^{13}$

Despite the Trump Administration's positions, there are some rays of hope. At the state and regional levels, politicians are finding ways to act on climate change through initiatives such as the United States Climate Alliance which aims to implement policies that will advance the goals of the Paris Agreement, regardless of federal government policies, and the Under2Coalition, an international coalition of state and regional governments committed to keeping global temperature rises to well below $2^{\circ} \mathrm{C}$. Similarly, the $\mathrm{C} 40$ Cities Climate Leadership Group is led by city mayors all around the world, who are also driving action on air quality and transport. Another fascinating initiative is Our Children's Trust which aims to secure the legal right of youth to a stable climate and healthy atmosphere and advocates for legally binding, science-based climate policies (https://www.ourchildrenstrust. org/). They are currently suing the US government.

Other factors are also in action, many of the EPAs efforts at deregulation are being subject to legal challenge. The coal industry, a presumed beneficiary of President Trump's policies and the EPA's deregulations, is still slowing down. US coal consumption is continuing to decline and is expected to be close to half less than it was in 2007 and the potential for exports is also declining. ${ }^{14}$

For the respiratory community, the public health impacts of climate change mean that environmental protection is very much 'in our lane'. ${ }^{15}$ As healthcare professionals, we must advocate for our patients-climate change increases the incidence of lung disease, worsens its severity and disrupts the ability of human societies, not only in low-income and middle-income countries, to deliver healthcare. ${ }^{16}$ Air pollution from fossil fuels and forest fires is harming our patients now and through its impact on the development of children's lungs ${ }^{17}$ is storing up lung disease for the future. We must also ensure that patients themselves are aware of the dangers of climate change, an awareness that will raise the political cost of inaction or of actions that are now making the situation worse. Our patients and their families should be encouraged to demand that their elected officials take the necessary steps to provide citizens with clean air, healthy non-polluting transport options and access to healthcare (table 1). This must also be a core activity for patient advocacy organisations.

We would like to stress that we do not consider these arguments to arise from a position based in party politics. Instead, we regard this as an ethical imperative stemming from our commitment to the Hippocratic Oath, and the Declaration of Geneva to attend to the health and well-being of our patients, and to do no harm. On climate change, a significant but preventable health risk to all of us and to future generations, ${ }^{18}$ silence is consent, and we must not be silent.

Twitter Nicholas S Hopkinson @COPDdoc, Nicholas Hart @NickHartThorax, Gisli Jenkins @IPFdoc, Naftali Kaminski @KaminskiMed, Alan Smyth @AlanRSmyth, AlexWilkinson@DrAlexWilkinson.

Contributors NSH and NK wrote the first draft on which all authors commented and approved the final version.

Funding The authors have not declared a specific grant for this research from any funding agency in the public, commercial or not-for-profit sectors.

Competing interests None declared.

Patient consent for publication Not required.

Provenance and peer review Commissioned; internally peer reviewed.

(c) Author(s) (or their employer(s)) 2019. No commercial re-use. See rights and permissions. Published by BMJ.

\section{A Check for updates}

To cite Hopkinson NS, Hart N, Jenkins G, et al. Thorax 2019:74:627-628.

Accepted 5 March 2019

Published Online First 21 April 2019

Thorax 2019;74:627-628.

doi:10.1136/thoraxinl-2019-213184

\section{REFERENCES}

1 Hopkinson NS, Hart N, Jenkins G, et al. Climate change and lung health: the challenge for a new president. Thorax 2017:72:295-6.

2 Woodcock A. The President speaks: prevention is best: lessons from protecting the ozone layer. Thorax 2012;67:1028-31

3 Velders GJM, Andersen SO, Daniel JS, et al. The importance of the Montreal protocol in protecting climate. Proceedings of the National Academy of Sciences 2007;104:4814-9.
4 Watts N, Adger WN, Agnolucci P, et al. Health and climate change: policy responses to protect public health. The Lancet 2015;386:1861-914.

5 McCarthy M. Trump's decision to leave climate pact threatens public health, US doctors warn. BMJ 2017;357.

6 Intergovernmental Panel on Climate Change. Global warming of $1.5^{\circ} \mathrm{C}, 2018$. Available: https://www.ipcc. ch/sr15/

7 Reidmiller DR, Avery CW, Easterling DR, et al, eds. Fourth national climate assessment, Volume II: Impacts, risks, and adaptation in the United States. Washington, DC, USA: U.S. Global Change Research Program, 2018.

8 Dawsey J, Rucker P, Dennis B, et al. Trump on climate change: 'People like myself, we have very high levels of intelligence but we're not necessarily such believers.'. Washington Post, 2018. Available: https://www.washingtonpost. com/politics/trump-on-climate-change-people-likemyself-we-have-very-high-levels-of-intelligencebut-were-not-necessarily-such-believers/2018/ 2011/2027/2722f0184-f2027e-2011e2018-aeeab2085fd44449f44445_story.html?noredirect=on\& utm_term $=. f a 44441$ b44448e42909c [Accessed 4th Feb 2019]

9 Seegert L. A year in health and healthcare under President Trump. BMJ 2018;360.

10 Grandoni D. The Energy 202: EPA adds researcher who calls climate science 'murky' to key advisory board, 2019. Available: https://www.washingtonpost.com/ news/powerpost/paloma/the-energy-202/2019/2002/ 2001/the-energy-2202-epa-adds-researcher-who-callsclimate-science-murky-to-key-advisory-board/2015 c5315f2061b2326b2029c3778d2035/?noredirect= on\&utm_term =.c2028dec2012f2056c2017

11 Friedman L, E.P.A N. Plan could free coal plants to release more mercury into the air. New York Times, 2018. Available: https://www.nytimes.com/2018/ 2012/2028/climate/mercury-coal-pollution-regulations. html

12 Randall C. Trump condemned over plans to allow drilling near national parks. The Guardian, 2018. Available: https://www.theguardian.com/environment/ 2018/sep/2014/conservatives-democrats-trumpdrilling-national-parks

13 Cutler D, Dominici F. A breath of BAD air: cost of the Trump environmental agenda may lead to 80000 extra deaths per DecadeA breath of BAD air: cost of the Trump environmental agenda may lead to 80 000 extra deaths per DecadeThe JAMA forum. JAMA 2018:319:2261-2.

14 Jones C, Trump's US. Coal consumption is less than Obama's. Forbes, 2019. Available: https://www. forbes. com/sites/chuckjones/2019/2001/2001/trumps-u-scoal-consumption-is-less-than-obamas/\#2014b201 9be2010d2005fa2018

15 Ho V. 'Do you know how many bullets I pull out of corpses weekly?' - doctors to NRA. The Guardian 2018:11/11/18. Available: https://www.theguardian. com/us-news/2018/nov/2009/nra-doctors-tweet-guncontrol-deaths [Accessed 2011th Jan 2019].

16 Watts N, Amann M, Ayeb-Karlsson S, et al. The Lancet countdown on health and climate change: from 25 years of inaction to a global transformation for public health. The Lancet 2018;391:581-630.

17 Gauderman WJ, Urman R, Avol E, et al. Association of improved air quality with lung development in children. New England Journal of Medicine 2015;372:905-13.

18 Samet JM, Burke TA, Goldstein BD. The Trump administration and the environment - Heed the science. New England Journal of Medicine 2017:376:1182-8. 